\title{
PENGARUH KECERDASAN EMOSIONAL DAN KOMPETENSI KEPRIBADIAN GURU TERHADAP PRESTASI BELAJAR SISWA MADRASAH ALIYAH DI PONDOK PESANTREN QOTRUN NADA DEPOK
}

\author{
Nani Prihatini (naniprihatini@al-kharaj.net GSaSt8AAAAJ\&hl) \\ Nanat Fatah Natsir, Amie Primarni \\ Program Pascasarajana \\ Institut Agama Islam Nasional (IAI-N) Bogor
}

\section{ABSTRACT}

The purpose of this research is to examine the influence of the teacher's emotional intelligence to the students 'learning achievements, there is no influence of the teacher's personality competence on student learning achievements, and there is no influence on the emotional intelligence and personality competence of the teacher simultaneously on student learning achievement. The method used in this study is quantitative. With the number of respondents 154 students Madrasah Aliyah Qotrun Nada Depok. The approach used is multiple linear regression, consisting of two free variables, i.e. emotional intelligence and teacher personality competence. The variables are students 'learning achievements. From the results of research obtained, that there is the influence of the teacher's emotional intelligence to the learning achievement students of Madrasah Aliyah Qotrun Nada. It is evidenced by the test value T, the value of sig $0.001<0.05$ then Ho rejected and Ha accepted. There is the influence of teacher personality competence on learning achievement of Madrasah Aliyah Qotrun Nada. It is evidenced by the test value T, the value of sig $0.000<0.05$ then Ho rejected and Ha accepted. The emotional intelligence and personality competence of the teacher contributed concurrently to the learning achievement as much as $35.5 \%$, it is evidenced by the test $F$.

Keywords: Emotional intelligence, personality competence and achievements.

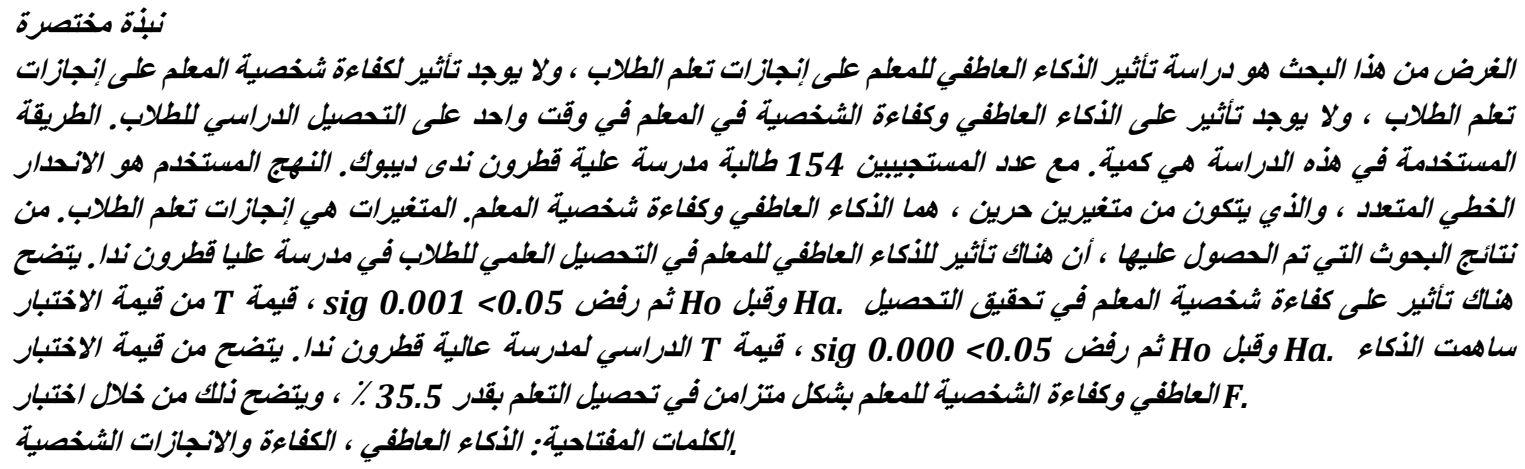




\begin{abstract}
ABSTRAK
Tujuan dari penelitian ini adalah, meneliti ada tidaknya pengaruh kecerdasan emosional guru terhadap prestasi belajar siswa, ada tidaknya pengaruh kompetensi kepribadian guru terhadap prestasi belajar siswa, dan ada tidaknya pengaruh kecerdasan emosional dan kompetensi kepribadian guru secara bersamaan terhadap prestasi belajar siswa. Metode yang digunakan dalam penelitian ini adalah kuantitatif. Dengan jumlah responden 154 siswa-siswi Madrasah Aliyah Qotrun Nada Depok. Pendekatan yang digunakan adalah regresi linier berganda, yang terdiri dari dua variable bebas, yaitu kecerdasan emosional dan kompetensi kepribadian guru. Adapun variable terikatnya adalah prestasi belajar siswa. Dari hasil penelitian didapatkan hasil, bahwa ada pengaruh kecerdasan emosional guru terhadap prestasi belajar siswa madrasah aliyah Qotrun Nada. Hal ini dibuktikan dengan nilai uji t, nilai sig 0,001<0,05 maka Ho ditolak dan Ha diterima. Ada pengaruh kompetensi kepribadian guru terhadap prestasi belajar siswa madrasah aliyah Qotrun Nada. Hal ini dibuktikan dengan nilai uji t, nilai sig 0,000< 0,05 maka Ho ditolak dan Ha diterima. Kecerdasan emosional dan kompetensi kepribadian guru berkontribusi bersamaan terhadap prestasi belajar sebanyak 35,5\%, hal ini dibuktikan dengan uji f.
\end{abstract}

Kata kunci : kecerdasan emosional, kompetensi kepribadian dan prestasi.

\title{
A. PENDAHULUAN
}

\section{Latar Belakang Masalah}

Sumber daya yang berkualitas adalah mereka yang memiliki kecerdasan -kecerdasan yang tinggi. Pada awalnya masyarakat menyakini bahwa, bagi mereka yang memiliki kecerdasan intelektual yang tinggi maka mereka miliki prestasi belajar yang tinggi pula dan kecerdasan intelektual menjadi peran penting dalam kehidupan seseorang. Menjadi jaminan akan lebih mudah untuk mendapatkan sebuah pekerjaan, dan menjamin bahwa masa depan akan lebih cerah, sehingga mereka lupa bahwa dalam diri manusia memiliki potensi yang lain yang juga tidak kalah pentingnya disamping kecerdasan intelektual.

Tidak lama kemudian muncul teori kecerdasan emosional (EQ) yang diperkenalkan oleh Daniel Goleman. Sebuah penelitian yang dilakukan oleh Daniel Goleman menunjukkan bahwa kecerdasan intelektual (IQ) hanya menyumbang $20 \%$ saja dalam keberhasilan manusia. Sisanya $80 \%$ bergantung pada kecerdasan emosional (EQ) yang kita miliki. Kecerdasan emosional (EQ) adalah kemampuan seseorang untuk menerima, menyetujui, mengatur, serta mengendalikan dirinya sendiri dan orang lain di sekitarnya (wikepedia). Sebaliknya, kecerdasan emosional (EQ) mempertimbangkan lipat kali lebih penting dibandingkan kecerdasan intelektual (IQ). Sejak saat itu , manusia mulai menyadari bahwa kesuksesan itu tidak hanya didasari oleh kecerdasan intelektual (IQ) saja, namun mesti ada keseimbangan antara kecerdasan intelektual (IQ) dan kecerdasan emosional (EQ). ${ }^{1}$

Selain kecerdasan emosional, kompetensi guru juga menjadi salah satu faktor yang dapat mempengaruhi prestasi belajar siswa. Guru yang memiliki kompetensi sangatlah berpengaruh dengan prestasi belajar yang akan diraih oleh siswa. Kecerdasan emosional

\footnotetext{
${ }^{1}$ Abd.Wahab H.S. \& Umiarso, Kepemimpinan Pendidikan dan Kecerdasan Spiritual, ( Jogjakarta:AR-RUZZ MEDIA,2011), I,hal 7
} 
dan kompetensi guru yang tinggi maka proses belajar mengajar akan lebih menyenangkan sehingga memungkin siswa untuk memberikan perhatian yang tinggi terhadap proses belajar mengajar.

Dalam perspektif kebijakan nasional, pemerintah telah merumuskan empat jenis kompetensi guru,sebagaimana tercantum dalam Penjelasan Peraturan Pemerintah No. 19 Tahun 2005 tentang Standar Nasional Pendidikan, yaitu: kompetensi pedagogis, kepribadian, sosial, dan professional. Guru diharapkan dapat menjalankan tugasnya secara professional dengan memiliki dan menguasai keempat kompetensi tersebut. Kompetensi yang harus dimiliki pendidik itu sungguh sangat ideal sebagaimana tergambar dalam peraturan pemerintah tersebut. Karena itu, guru harus selalu belajar dengan tekun di selasela menjalankan tugasnya. Menjadi guru professional bukan pekerjaan yang mudah-untuk tidak mengatakannya sulit, apalagi di tengah kondisi mutu guru yang sangat buruk dalam setiap aspeknya. ${ }^{2}$

Kompetensi kepribadian, yaitu "Kemampuan kepribadian yang (a) berakhlak mulia; (b) mantap, stabil, dan dewasa; (c) arif dan bijaksana; (d) menjadi teladan; (e) mengevaluasi kinerja sendiri; (f) mengembangkan diri; dan (g) religious." (BNSP, 2006: 88)33. Kompetensi kepribadian merupakan salah satu jenis kompetensi yang perlu dimiliki oleh seorang guru, karena kompetensi ini menggambarkan tentang etika,akhlak dan teladan guru.

Kecerdasan emosional dan kompetensi kepribadian guru sangat diperlukan dalam proses kegiatan belajar mengajar, kecerdasan emosinal guru tidak dapat bekerja secara maksimal jika tidak didukung dengan kompetensi kepribadian guru terhadap prestasi belajar siswa. Kecerdasan emosional dan kompetensi kepribadian yang dimiliki setiap guru saling bersinergi dalam melaksanakan proses belajar mengajar, sehingga keseimbangan dari keduanya dapat berpengaruh dalam meningkatkan prestasi belajar siswa.

Atas dasar tersebut di atas, maka peneliti tertarik untuk meneliti kecerdasan emosional dan kompetensi kepribadian guru. Mengingat guru adalah sebagai tenaga pengajar dan pendidik serta menjadi teladan bagi para siswanya, baik secara moral maupun intelektual. Sehingga peneliti mengambil judul : "Pengaruh Kecerdasan Emosional Dan Kompetensi Kepribadian Guru Terhadap Prestasi Belajar Siswa Madrasah Aliyah Di Pondok Pesantren Qotrun Nada Depok".

\section{Rumusan Masalah}

Berdasarkan identifikasi dan latar belakang masalah di atas, maka masalah-masalah dalam penelitian ini dapat dirumuskan sebagai berikut :

1. Apakah ada pengaruh kecerdasan emosional guru terhadap prestasi belajar siswa?

2. Apakah ada pengaruh kompetensi kepribadian guru terhadap prestasi belajar siswa?

3. Apakah ada pengaruh kecerdasan emosional dan kompetensi kpribadian guru bersama-sama terhadap prestasi belajar siswa?

\footnotetext{
${ }^{2}$ Jejen Musfah, Peningkatan Kompetensi Guru, ( Jakarta:PRENADAMEDIA GROUP,2015 ),III,hal 30

${ }^{3}$ Jejen Musfah, Peningkatan Kompetensi Guru, ( Jakarta:PRENADAMEDIA GROUP,2015 ),III,hal 43
} 


\section{Tujuan Penelitian}

Berdasarkan rumusan masalah yang telah digambarkan diatas, maka penelitian ini bertujuan untuk mengetahui :

1. Pengaruh kecerdasan emosional guru terhadap prestasi belajar siswa

2. Pengaruh kompetensi kepribadian guru terhadap prestasi belajar siswa

3. Pengaruh kecerdasan emosional dan kompetensi kepribadian guru bersama-sama terhadap prestasi belajar siswa.

\section{Hipotesis}

Untuk mengetahui pengaruh kecerdasan emosional dan kompetensi kepribadian guru terhadap prestasi belajar siswa di Pondok Pesantren Qotrun Nada Depok maka diperlukan asumsi dasar yang merupakan titik tolak pemikiran bagi setiap pandangan untuk menentukan jawaban atas permasalahan yang sedang diteliti. Menurut Suharsimi Arikunto asumsi atau anggapan dasar adalah : "Suatu hal yang diyakini kebenarannya oleh peneliti, yang harus dirumuskan secara jelas". ${ }^{4}$

Penelitian tentang pengaruh kecerdasan emosional dan kompetensi kepribadian guru terhadap prestasi belajar siswa didasarkan pada asumsi-asumsi sebagai berikut:

Dalam penelitian ini, hipotesis peneliti sebagai berikut :

1. Jika kecedasan emosional gurunya baik, maka prestasi belajar siswanya baik.

2. Jika kompetensi kepribadian gurunya baik, maka prestasi belajar siswanya baik.

3. Jika kecerdasan emosional dan kompentensi kepribadian guru sama-sama baik, maka prestsai belajar siswanya baik.

\section{B. TINJAUAN PUSTAKA DAN STUDI TERDAHULU}

\section{Kerangka Pemikiran}

Dalam rumusan masalah dan pemaparan yang telah diurai di atas yang menjadi dasar penelitian, maka kerangka berpikir penelitian ini ada dua variabel bebas dan satu variabel terikat sebagi berikut :

a. Variabel bebas pertama diberi simbol ( X1 ), yaitu kecerdasan emosional dengan indikator pengukuran :(1) kemampuan untuk mengenal dan mengelola emosi (2) kemampuan untuk memotivasi dan memberi dorongan untuk maju (3) kemampuan untuk mengenal emosi dan kepribadian orang lain (4) kemampuan untuk membina hubungan baik dengan yang lain.

b. Variabel bebas kedua diberi simbol ( X2 ), yaitu kompetensi kepribadian guru dengan indikator pengukuran : (1) akhlak dan teladan yang baik (2) mengevaluasi kinerja kinerja sendiri (3) mengembangkan diri secara berkelanjutan.

${ }^{4}$ Arikunto, S. Dasar-Dasar Evaluasi Pendidikan,(Jakarta:Bumi Aksara, 1995)hal 53 
c. Variabel terikat diberi simbol ( Y ),yaitu prestasi belajar siswa dengan indikator pengukuran : aspek prestasi belajar dan faktor yang mempengaruhi prestasi belajar.

Kerangka Pemikiran :

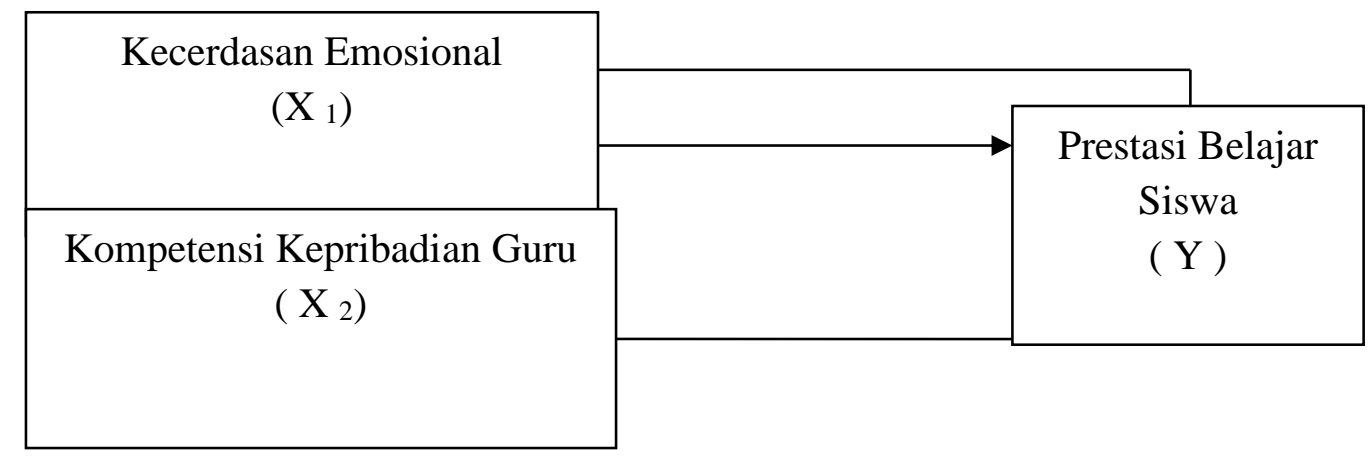

\section{Kecerdasan Emosional}

Istilah kecerdasan emosi pertama kali berasal dari konsep kecerdasan social yang dikemukakan oleh Thordike pada tahun 1920-an dan 1930-an, dalam artikel di Harper's Magazine menyatakan bahwa salah satu aspek kecerdasan emosional, yaitu kecerdasan social, kemampuan untuk memahami orang lain dan bertindak bijaksana dalam hubungan antar manusia. ${ }^{5}$

Teori mengenai kecerdasan emosional pertama kali dicetuskan oleh Salovey dan Mayer tahun 1990. Mereka (Salovey dan Mayer) mendefinisikan kecerdasan emosional atau yang sering disebut EQ sebagai "himpunan bagian dari kecerdasan social yang melibatkan kemampuan memantau perasaan social yang melibatkan kemampuan pada orang lain, memilah-milah semuanya dan menggunakan informasi ini untuk membimbing pikiran dan tindakan."6

Menurut Goleman, kecerdasan emosional adalah kemampuan seseorang mengatur kehidupan emosinya dengan inteligensi, menjaga keselarasan emosi dan pengungkapannya melalui keterampilan kesadaran diri, pengendalian diri, motivasi diri, empati dan keterampilan social. ${ }^{7}$

Kecerdasan emosional menurut Daniel Goleman dari Salovey menempatkan kecerdasan pribadi Gardner dalam definisi dasar tentang kecerdasan emosional yang dicetuskannya, seraya memperluas kemampuan ini menjadi lima wilayah utama, ${ }^{8}$ yaitu :

1. Mengenali Emosi Diri

2. Mengelola Emosi

5 Daniel Goleman, Emotional Intelligence,Kecerdasan Emosional,(Jakarta:PT Gramedia pustaka utama,2000)hal,56

${ }^{6}$ Jurnal Formatif 6(3):233-245, 2016 , hal 234

${ }^{7}$ Jurnal Formatif 6(3):233-245, 2016 , hal 236

8 Daniel Goleman, Emotional Intelligence,Kecerdasan Emosional,(Jakarta:PT Gramedia pustaka utama,2000)hal,57 


\section{Memotivasi Diri Sendiri}

4. Mengenali Emosi Orang Lain

5. Membina Hubungan

\section{Kompetensi Kepribadian Guru}

Menurut Undang-Undang No. 14 tahun 2005 tentang Guru dan Dosen, kompetensi adalah seperangkat pengetahuan, keterampilan, dan perilaku yang harus dimiliki, dihayati, dan dikuasai oleh guru atau dosen dalam melaksanakan tugas keprofesionalan. ${ }^{9}$

Menurut Gordon Allport (1951), seorang psikolog Jerman yang merupakan pakar kepribadian, kepribadian adalah organisasi dinamis dalam individu sebagai system psikofisik yang menentukan caranya yang khas dalam menyesuaikan diri terhadap lingkungan ${ }^{10}$.

Dengan demikian, guru harus memiliki sikap kepribadian yang mantap sehingga mampu menjadi sumber inspirasi bagi peserta didik. Guru harus mampu menjadi tri pusat, seperti ungkapan Ki Hajar Dewantoro “Ing Ngarso Sung tulodo, Ing Madya Mangun Karso, Tut Wuri Handayani”, di depan memberikan teladan, di tengah memberikan karsa, dan di belakang memberikan dorongan / motivasi.11

Kompetensi kepribadian, yaitu "Kemampuan kepribadian yang :(a) berakhlak mulia; (b) mantap, stabil, dan dewasa; (c) arif dan bijaksana; (d) menjadi teladan; (e) mengevaluasi kinerja sendiri; (f) mengembangkan diri; dan (g) religious."12

Aspek tertinggi dari kebergaman seseorang ialah saat seluruh aktivitas kehidupannya, baik duniawi maupun ukhrowi hanya didasari untuk meraih keridhoan Alloh SWT. Maka, seorang guru yang religius pasti akan membimbing siswanya untuk memiliki kepribadian yang luhur dan utama, terutama akhlak pada Tuhan lalu akhlak pada sesama makhluk hidup di sekelilingnya. Ilmu akan hampa dan tiada manfaat, bahkan cenderung menghancurkan nilai-nilai kemanusiaan, jika tidak dimiliki oleh pribadi yang religious dan berakhlak ${ }^{13}$.

Sebagian masyarakat jika menemukan siswa yang berperilaku tidak baik terkadang mereka akan mengatakan, sekolah dimana, siapa gurunya, dan entah kaliamat apa lagi. Kritik ini perlu diperhatikan oleh setiap lembaga pendidikan, bahwa sekolah yang hebat, sarana dan prasarana pendidikan yang canggih, namun tidak dibarengi dengan pembinaan kepribadian dan karakter guru maka penilaian masyarakat akan semakin memburuk terhadap lembaga tersebut. Dari sini terlihat bahwa guru merupakan sosok yang berpengaruh dalam perilaku dan kepribadian siswa, yang pada akhirnya pula akan berpengaruh terhadap sebuah prestasi.

\footnotetext{
9 Undang-Undang No. 14 tahun 2015, tentang guru dan dosen.

${ }^{10}$ Inge hutagulung, Pengembangan Kepribadian,(Jakarta:PT Indeks,2007)hal 1

${ }^{11}$ Donni Juni Priansa, Menjdai Kepala Sekolah Dan Guru Profesional,(Bandung:CV Pustaka Setia,2017)hal 176.

12 Jejen Musfah, Peningkatan Kompetensi Guru, ( Jakarta:PRENADAMEDIA GROUP,2015 ),III,hal $42 \& 43$

${ }^{13}$ Jejen Musfah, Peningkatan Kompetensi Guru, ( Jakarta:PRENADAMEDIA GROUP,2015 ),III,hal 51
} 


\section{Prestasi Belajar Siswa}

Prestasi belajar merupakan faktor yang sangat penting bagi siswa didik maupun bagi pendidik. Prestasi belajar yang baik merupakan cita-cita setiap siswa maupun pendidik. Karena prestasi belajar siswa merupakan sebuah tolak ukur keberhasilan proses belajar mengajar yang dilakukan oleh siswa dan pendidik. Apabila prestasi yang didapatkan siswa baik, maka dapat dikatakan proses belajar mengajar berhasil baik, akan tetapi jika prestasi belajar yang dicapai siswa rendah, maka dapat dikatakan behwa proses belajar mengajar yang dilakukan oleh guru belum berhasil dengan baik.

Usaha untuk mengetahui Prestasi Belajar siswa dilakukan melalui evaluasi. Evaluasi dimaksudkan untuk melihat sampai sejauh mana langkah bantuan yang telah diberikan untuk mencapai hasil yang diharapkan. Dengan evaluasi dapat ditentukan tingkat keberhasilan suatu program, sekaligus juga dapat diukur hasil-hasil yang dicapai oleh suatu program ${ }^{14}$.

Prestasi belajar menurut Winkel (kodir,2011) mengemukakan bahwa prestasi belajar merupakan bukti keberhasilan yang telah dicapai oleh seseorang. Dengan demikian, prestasi belajar merupakan hasil maksimum yang dicapai oleh seseorang setelah melaksanakan usaha-usaha belajar ${ }^{15}$.

\section{Aspek-aspek Prestasi Belajar}

Benyamin S, Bloom mengemukakan bahwa tiga aspek (domain): 1. Kognitif, 2. Afektif, 3. Psikomotorik. ${ }^{16}$ Berdasarkan beberapa pendapat sebelumnya, maka dapat disimpulkan bahwa prestasi belajar adalah sebagai hasil penilaian yang diambil dari proses pembelajaran dalam waktu tertentu baik secara individu atau kelompok dan sebagai ukuran perkembangan peserta didik dalam pengetahuan dan keterampilan, sehingga peserta didik dapat meningkatkan kreatifitas dan aktifitas dalam mengkomunikasikan pengetahuannya baik secara lisan maupun tertulis.

Prestasi belajar adalah sesuatu yang dapat dicapai baik pengetahuan, sikap, maupun keterampilan yang dicapai seorang individu dan merupakan hasil interaksi antara berbagai yang mempengaruhi baik dari dalam diri maupun dari luar diri individu.

\section{Hasil Penelitian Terdahulu}

Tabel 1.1

\begin{tabular}{|l|l|l|l|l|}
\hline NO. & $\begin{array}{l}\text { Nama Peneliti, } \\
\text { Tahun, dan Judul } \\
\text { Pnelitian }\end{array}$ & Persamaan & Perbedaan & $\begin{array}{l}\text { Orisinilitas } \\
\text { Penelitian }\end{array}$ \\
\hline 1. & $\begin{array}{l}\text { Iman Firmansyah, } \\
2010, \quad \text { Pengaruh } \\
\text { Tingkat Kecerdasan } \\
\text { Emosional Terhadap }\end{array}$ & & $\begin{array}{l}\text { Penelitian } \\
\text { membahas } \\
\text { tentang }\end{array}$ & $\begin{array}{l}\text { Meningkatkan } \\
\text { Prestasi } \\
\text { Belajar }\end{array}$ \\
\hline
\end{tabular}

\footnotetext{
14 Jurnal Formatif 6(3):233-245, 2016

${ }^{15}$ https://www.universitaspsikologi.com

${ }^{16}$ Sitti Salmiah Dahlan, Manajemen Pendidikan Islam,(Jakarta:Rabbani Pres,2011), hal 213
} 


\begin{tabular}{|c|c|c|c|c|}
\hline & $\begin{array}{l}\text { Prestasi } \quad \text { Belajar } \\
\text { siswa. }\end{array}$ & & $\begin{array}{l}\text { tingkatan } \\
\text { emosional. }\end{array}$ & \\
\hline 2. & $\begin{array}{lr}\text { Indah } & \text { Mayang } \\
\text { Purnama, } & 2016, \\
\text { Pengaruh } & \\
\text { Kecerdasan } & \\
\text { Emosional } & \text { Dan } \\
\text { Minat } & \text { Belajar } \\
\text { Terhadap } & \text { Prestasi } \\
\text { Belajar Matematika. }\end{array}$ & Mutu & $\begin{array}{l}\text { Meningkatkan } \\
\text { minat belajar } \\
\text { matematika. }\end{array}$ & $\begin{array}{l}\text { Prestasi } \\
\text { Belajar }\end{array}$ \\
\hline 3. & $\begin{array}{lr}\text { Elli Marlinda, 2017, } \\
\text { Pengaruh } \\
\text { Kompetensi } \\
\text { Kepribadian } & \text { Guru } \\
\text { Terhadap Prestasi } \\
\text { Belajar } \quad \text { Peserta } \\
\text { Didik. }\end{array}$ & Mutu & $\begin{array}{l}\text { Mencakup } \\
\text { Empat Aspek } \\
\text { Kompetensi } \\
\text { Guru. }\end{array}$ & $\begin{array}{l}\text { Meningkatkan } \\
\text { Prestasi } \\
\text { Belajar }\end{array}$ \\
\hline 4. & $\begin{array}{lr}\text { Ahmad } & \text { Razak, } \\
\text { Novita } & \text { Maulidya } \\
\text { Jalal, } & \text { 2018, } \\
\text { Hubungan } & \text { Antara } \\
\text { Kecerdasan } & \\
\text { Emosional } & \text { Dan } \\
\text { Kompetensi } & \\
\text { Kepribadian Guru. }\end{array}$ & Mutu & $\begin{array}{l}\text { Meningkatkan } \\
\text { Kemampuan } \\
\text { Kecerdasan } \\
\text { Emosional } \\
\text { Guru dan } \\
\text { Kompetensi } \\
\text { Kepribadian } \\
\text { Guru. }\end{array}$ & $\begin{array}{l}\text { Meningkatkan } \\
\text { Prestasi } \\
\text { Belajar Siswa }\end{array}$ \\
\hline
\end{tabular}

Dalam penelitian yang lain menunjukkan bahwa kecerdasan emosional dapat memberikan pengaruh terhadap prestasi belajar siswa dengan prosentase $17,55 \%$, walau angka ini tidak terlalu besar namun berdasarkan penelitian tersebut dapat membuktikan bahwa, kecerdasan emosional dapat memberikan pengaruh terhadap prestasi belajar.

Berdasarkan pemaparan peneliti terdahulu bahwa kompetensi kepribadian dapat memberikan pengaruh terhadap prestasi belajar, walau tingkat hubungan kompetensi kepribadian guru dengan prestasi belajar tidak terlalu kuat. Namun seacara teoritis prestasi belajar peserta didik akan meningkat jika kompetensi kepribadian guru juga meningkat.

Kecerdasan emosional dengan kompetensi kepribadian, memberikan makna bahwa bentuk kecerdasan emosional penting untuk dimiliki dan dikembangakan bagi seorang guru agar semakin memperbaiki kompetensi kepribadiannya. Seorang guru yang memiliki kompetensi kepribadian dapat menghayati peran statusnya sebagai guru, mengenali dan mengendalikan emosi sendiri serta menghargai siswa. 


\section{METODOLOGI PENELITIAN}

\section{Pendekatan dan Metode Penelitian}

Metode kuantitatif dinamakan metode tradisional, karena metode ini sudah cukup lama digunakan sehingga sudah mentradisi sebagai metode untuk penelitian. Metode ini disebut sebagai metode positivistic karena berlandaskan pada filsafat positivisme. Metode ini sebagai metode ilmiah/scientific karena telah memenuhi kaidah-kaidah ilmiah yaitu konkrit/empiris, obyektif, terukur, rasional, dan sistematis. ${ }^{17}$

Penelitian ini menggunakan penelitian yang bersifat kuantitatif yang bertujuan untuk mengetahui pengaruh dua variable atau lebih yang bersifat sebab akibat, menguji teori dan analisa data dengan menggunakan statistic untuk menguji hipotesis ${ }^{18}$.

Penelitian ini bersifat kuantitatif dengan memakai pendekatan regresi berganda. Dalam studi lapangan desain penelitian dengan mengkombinasi antara pencarian literature dengan survey pengalaman lapangan di sekolah atau studi kasus. Usaha mengidentifikasi variable-variabel penelitian dan hubungan antar variable tersebut dalam suatu situasi permasalahan tertentu. Studi lapangan digunakan sebagai sarana penelitian lebih lanjut dan mendalam.

\section{Populasi dan Sampel}

Populasi adalah wilayah generalisasi yang terdiri atas : obyek/subyek yang mempunyai kualitas dan karakteristik tertentu yang ditetapkan oleh peneliti untuk dipelajari dan kemudian ditarik kesimpulannya. Jadi populasi bukan hanya orang, tetapi juga obyek dan benda-benda alam yang lain. Populasi juga bukan sekedar jumlah yang ada pada obyek/subyek yang dipelajari, tetapi meliputi seluruh karakteristik/sifat yang dimiliki oleh subyek atau obyek itu. ${ }^{19}$

Maka peneliti akan melakukan penelitian di Pondok Pesantren Qotrun Nada, dan Pondok Pesantren Qotrun Nada mempunyai sejumlah orang atau subyek serta beberapa obyek lainnya. Subyek dan obyek yang terdapat di Pondok Pesantren Qotrun Nada memiliki beberapa karakteristik atau sifat yang akhirnya nanti akan digunakan sebagai populasi dalam penelitian.

Untuk mewakili populasi yang telah ditetapkan dalam penelitian ini maka diperlukan sampel sebagai cerminan guna menggambarkan keadaan populasi dan lebih mudah dalam melakukan penelitian. Jika kita hanya akan meneliti sebagian dari populasi, maka penelitian tersebut disebut penelitian sampel. Sampel adalah sebagian atau wakil populasi yang diteliti 20 .

Teknik yang digunakan dalam pengambilan sampel ini adalah Proportional Stratified Random Sampling, yaitu dari jumlah populasi ditentukan jumlah sampel sebagai obyek penelitian. Pengambilan sampel dilakukan secara merata, sehingga semua responden mempunyai kesempatan atau peluang yang sama sebagai anggota sampel.

17 Sugiono, Metode Penelitian,(Bandung:Alfabeta,2017),26,hal 7

${ }^{18}$ Sugiono, Metode penelitian Kuantitatif, Kualitatif dan R\&D,23-24

19 Sugiono, Metode Penelitian,(Bandung:Alfabeta,2017),26,hal 80

${ }^{20}$ Suharsimi Arikunto,Manajemen Penelitian,(Jakarta:Reneka Cipta,1992),174 
Proportional Stratified Random Sampling, teknik ini digunakan bila populasi mempunyai anggota/unsure yang tidak homogeny dan berstrata secara proporsional. Proportional Stratified Random Sampling merupakan bagian dari Probability Sampling. Probability Sampling adalah teknik pengambilan sampel yang memberikan peluang yang sama bagi setiap unsure (anggota) populasi untuk dipilih menjadi anggota sampel 21 .

Untuk membuktikan kebenaran jawaban yang masih sementara (hipotesis), maka peneliti melakukan pengumpulan data pada obyek tertentu. Karena obyek dalam populasi terlalu luas, maka peneliti menggunakan sampel yang diambil dari populasi tersebut.

Karena jumlah subjek populasi termasuk kategori besar, yaitu 772 maka peneliti mengambil 20\%. Jika jumlah subjeknya besar, dapat diambil antara 10-15\% atau 20-25\% atau lebih 22 .

Dari ukuran sampel yang telah diketahui, selanjutnya peneliti akan menentukan perwakilan dari tiap kelas. Data perhitungan proporsi sampel perwakilan tiap kelas dapat dilihat dalam tabel di bawah ini:

Tabel 3.1 perhitungan proporsi sampel dalam perwakilan tiap kelas

\begin{tabular}{|l|l|l|l|l|}
\hline No. & Kelas & Populasi & $\begin{array}{l}\text { Proporsi } \\
\text { Sampel }\end{array}$ & $\begin{array}{l}\text { Jumlah } \\
\text { Sampel }\end{array}$ \\
\hline 1. & X \& THS1 & 302 & $20 \%$ & 60 \\
\hline 2. & XI \& THS 2 & 279 & $20 \%$ & 56 \\
\hline 3. & XII \& THS 3 & 191 & $20 \%$ & 38 \\
\hline Jumlah & $\mathbf{7 7 2}$ & & $\mathbf{1 5 4}$ \\
\hline
\end{tabular}

Dengan demikian proporsi sampel menjadi jelas dan setiap populasi mendapatkan kesempatan dan peluang yang sama.

\section{Teknik Analisis Data}

Dalam penelitian kuantitatif, analisi data merupakan kegiatan setelah data dari seluruh responden atau sumber data lain terkumpul. Kegiatan dalam analisis data adalah : mengelompokkan data berdasarkan variable dan jenis responden, mentabulasi data berdasarkan variable dari seluruh responden, menyajikan data tiap variable yang diteliti, melakukan perhitungan untuk menjawab rumusan masalah, dan melakukan perhitungan untuk menguji hipotesis yangtelah diajukan ${ }^{23}$.

Analisis data adalah proses penyederhanaan data ke dalam bentuk yang lebih mudah dibaca dan diinterprestasikan. Metode analisis data yang digunakan dalam penelitian ini adalah metode kuantitatif, yang digunakan untuk mengukur suatu fenomena penelitian

\footnotetext{
${ }^{21}$ Sugiono, Metode Penelitian,(Bandung:Alfabeta,2017),26,hal 82

${ }^{22}$ Suharsimi Arikunto,Prosedur Penelitian,(Jakarta:Rineka Cipta,2006), 134

${ }^{23}$ Sugiono, Metode Penelitian,(Bandung:Alfabeta,2017),26,hal 147
} 
dengan menggunakan alat bantu statistik. Metode statistik yang digunakan adalah analisis jalur yang menerangkan akibat langsung dan tidak langsung dari satu atau lebih variabel sebagai variabel penyebab terhadap satu atau lebih variabel lainnya sebagai variabel akibat. Setelah data-data yang diperlukan dalam penelitian ini terkumpul, selanjutnya adalah memproses dan menganalisa data.

Pada prinsipnya metode analisis data digunakan untuk mengelola data dengan metode statisk untuk mencari kesimpulan.

Analisis data yang digunakan dalam penelitian ini meliputi analisis statistik deskriptif dan analisis korelasi untuk menguji hipotesis penelitian. Analisis statistik deskriptif digunakan untuk mendeskripsikan statistik masing-masing variabel bebas yaitu kecerdasan emosional dan kompetensi kepribadian guru. Analisis statistik deskriptif juga diperlukan untuk mengetahui nilai kecenderungan data hasil penelitian yaitu dengan jalan mengurai atau menjabarkan data-data variabel penelitian (kecerdasan emosional, kompetensi kepribadian guru dan prestasi belajar siswa ).

Analisis data ini untuk mengelompokkan data supaya mudah dibaca dan dipahami. Mengkategorikan data akan memudahkan membaca kecenderungan yang terjadi pada objek penelitian dan hubungan antar variabel.

Penilaian masing-masing variable pada kuisioner yang disebarkan dihitung menggunakan skala likert, dengan pemberian skor berdasarkan pernyataan positif dan pernyataan negative. Skala likert digunakan untuk mengukur sikap,pendapat, dan persepsi seseorang atau sekelompok orang fenomena sosial24. Dalam penelitian, fenomena social ini telah ditetapkan secara spesifik oleh peneliti, yang selanjutnya disebut sebagai variable penelitian.

Dengan skala likert, maka variabel-variabel yang akan diukur dijabarkan menjadi indikator variabel. Kemudian indikator tersebut dijadikan sebagai titik tolak untuk menyusun item-item instrumen yang dapat berupa pernyataan atau pertanyaan.

Pengumpulan data variabel bebas dan variabel terikat dilakukan dengan angket. Analisi regresi digunakan untuk mengetahui predictor yang paling kuat dan predictor yang paling lemah diatara variabel bebas terdapat variabel terikat. Criteria masing-masing variabel pada analisis data mengacu pada interval skor dengan rumus sebagai berikut:

$$
\text { Skor Persentase }=\frac{\text { Skor rata-rata }}{\text { Skor maksimum }} \times 100 \%
$$

\section{HASIL PENELITIAN DAN PEMBAHASAN}

Data hasil pengolahan kuisioner yang telah disebarkan kepada peserta didik madrasah aliyah Qotrun Nada berjumlah 154 responden dengan pernyataan-pernyataan yang berkaitan dengan kecerdasan emosional guru dan kompetensi kepribadian guru, maka didapatkan hasil sebagai berikut.

Tabel 4.1 Prosentasi Jumlah Responden

\begin{tabular}{|l|l|l|l|}
\hline Kelas & Jumlah Siswa & Jumlah Responden & $\%$ \\
\hline X \& THS 1 & 302 & 60 & $39 \%$ \\
\hline
\end{tabular}

\footnotetext{
${ }^{24}$ Sugiono, Metode Penelitian,(Bandung:Alfabeta,2017),26,hal 93
} 


\begin{tabular}{|l|l|l|l|}
\hline XI \& THS 2 & 279 & 56 & $36 \%$ \\
\hline XII \& THS 3 & 191 & 38 & $25 \%$ \\
\hline Jumlah & 772 & 154 & $100 \%$ \\
\hline
\end{tabular}

Data tersebut menunjukkan bahwa responden yang paling banyak berasal dari tingkatan kelas X mencapai 39\% karena jumlah siswanya lebih banyak dibanding tingkatan kelas XI dan XII.

Tabel 4.2 Prosentase Jenis Kelamin Responden

\begin{tabular}{|l|l|l|}
\hline Jenis Kelamin & Jumlah & $\%$ \\
\hline Laki-laki & 293 & $38 \%$ \\
\hline Perempuan & 479 & $62 \%$ \\
\hline Jumlah & 772 & $100 \%$ \\
\hline
\end{tabular}

Berdasarkan tabel di atas maka sebagian besar responden berjenis kelamin perempuan, karena jumlah responden perempuan lebih banyak dibandingkan jumlah responden laki-laki. Dengan prosentasi $62 \%$ responden perempuan dan 38\% responden laki-laki.

\section{Variabel Kecerdasan Emosional Guru (X1)}

Berdasarkan setiap uraian pernyataan di atas menunjukan bahwa, rata-rata semua responden menyatakan jawabannya setuju dan bahkan sangat setuju, pernyataan tidak setuju lebih sedikit sekali. Sehingga dinyatakan bahwa mayoritas siswa menyatakan setuju dan sangat setuju, hal ini menunjukkan bahwa guru memiliki kecerdasan emosional yang terkait dengan indikator kecerdasan emosional.

Berdasarkan tabel di atas rata-rata keseluruhan variabel kecerdasan emosional guru sebesar 4,2 dengan prosentase 84\% dengan kategori sangat baik.

Distribusi frekuensi yang diperoleh dari penyebaran angket tentang kecerdasan emosional guru adalah: 


\begin{tabular}{|c|c|c|c|c|c|}
\hline \multicolumn{6}{|c|}{ Tabel 4.5 Distribusi Frekuensi Kecerdasan Emosional Guru } \\
\hline \multicolumn{6}{|c|}{ X1 } \\
\hline & & Frequency & Percent & $\begin{array}{c}\text { Valid } \\
\text { Percent }\end{array}$ & $\begin{array}{c}\text { Cumulative } \\
\text { Percent }\end{array}$ \\
\hline \multirow[t]{15}{*}{ Valid } & 35.00 & 1 & 0,6 & $\overline{0,6}$ & 0,6 \\
\hline & 36.00 & 2 & 1,3 & $\overline{1,3}$ & 1,9 \\
\hline & 37.00 & 6 & 3,9 & 3,9 & 5,8 \\
\hline & 38.00 & 5 & 3,2 & 3,2 & 9,1 \\
\hline & 39.00 & 13 & 8,4 & $\overline{8,4}$ & 17,5 \\
\hline & 40.00 & 8 & 5,2 & $\overline{5,2}$ & 22,7 \\
\hline & 41.00 & 21 & 13,6 & 13,6 & 36,4 \\
\hline & 42.00 & 9 & 5,8 & 5,8 & 42,2 \\
\hline & 43.00 & 31 & 20,1 & 20,1 & 62,3 \\
\hline & 44.00 & 14 & 9,1 & $\overline{9,1}$ & 71,4 \\
\hline & 45.00 & 26 & 16,9 & 16,9 & 88,3 \\
\hline & 46.00 & 6 & 3,9 & 3,9 & 92,2 \\
\hline & 47.00 & 11 & 7,1 & 7,1 & 99,4 \\
\hline & 49.00 & 1 & 0,6 & 0,6 & 100,0 \\
\hline & Total & 154 & 100,0 & 100,0 & \\
\hline
\end{tabular}

Dari hasil distribusi kuesioner tersebut dapat dilihat bahwa kecerdasan emosional guru paling banyak diangka 4,3 sebanyak 31 responden atau sebesar 20,1\%, lalu diangka 4,5 sebanyak 26 responden atau sebesar $16,9 \%$.

\section{Variabel Kompetensi Kepribadian Guru (X2)}

Berdasarkan setiap uraian pernyataan di atas menunjukan bahwa, rata-rata semua responden menyatakan jawabannya setuju dan bahkan sangat setuju, pernyataan tidak setuju lebih sedikit sekali. Sehingga dinyatakan bahwa mayoritas siswa menyatakan setuju dan sangat setuju, hal ini menunjukkan bahwa guru memiliki kompetensi kepribadian guru yang terkait dengan indikator kompetensi kepribadian guru.

Berdasarkan tabel di atas rata-rata keseluruhan variabel kompetensi kepribadian guru sebesar 4,3 dengan prosentase 86,\% dengan kategori sangat baik.

Distribusi frekuensi yang diperoleh dari penyebaran angket tentang kompetensi kepribadian guru adalah : 


\begin{tabular}{|c|c|c|c|c|c|}
\hline \multicolumn{6}{|c|}{ Tabel 4.8 Distribusi Frekuensi Kompetensi Kepribadian Guru } \\
\hline \multicolumn{6}{|c|}{$\mathrm{X2}$} \\
\hline & & Frequency & Percent & $\begin{array}{l}\text { Valid } \\
\text { Percent }\end{array}$ & $\begin{array}{c}\text { Cumulative } \\
\text { Percent }\end{array}$ \\
\hline \multirow[t]{16}{*}{ Valid } & 34.00 & 1 & 0,6 & 0,6 & 0,6 \\
\hline & 35.00 & 1 & 0,6 & $\overline{0,6}$ & $\overline{1,3}$ \\
\hline & 37.00 & 4 & 2,6 & 2,6 & $\overline{3,9}$ \\
\hline & 38.00 & 6 & 3,9 & $\overline{3,9}$ & 7,8 \\
\hline & $\overline{39.00}$ & 2 & 1,3 & 1,3 & 9,1 \\
\hline & 40.00 & 15 & 9,7 & 9,7 & 18,8 \\
\hline & 41.00 & 10 & 6,5 & 6,5 & 25,3 \\
\hline & 42.00 & 20 & 13,0 & 13,0 & 38,3 \\
\hline & 43.00 & 16 & 10,4 & 10,4 & 48,7 \\
\hline & 44.00 & 18 & 11,7 & 11,7 & 60,4 \\
\hline & 45.00 & 17 & 11,0 & 11,0 & 71,4 \\
\hline & 46.00 & 18 & 11,7 & 11,7 & 83,1 \\
\hline & 47.00 & 13 & 8,4 & 8,4 & 91,6 \\
\hline & 48.00 & 8 & $\overline{5,2}$ & 5,2 & 96,8 \\
\hline & 49.00 & 5 & 3,2 & 3,2 & 100,0 \\
\hline & Total & 154 & 100,0 & 100,0 & \\
\hline
\end{tabular}

Dari hasil distribusi kuesioner tersebut dapat dilihat bahwa kompetensi kepribadian guru paling banyak diangka 4,2 sebanyak 20 responden atau sebesar 13,0\%, lalu diangka 4,4 dan 4,6 sebanyak 18 responden atau sebesar 11,7\%.

\section{Variabel Prestasi Belajar Siswa (Y)}

Tabel 4.10 Distribusi Frekuensi Prestasi Belajar Siswa 


\begin{tabular}{|c|c|c|c|c|c|}
\hline & & Prestasi & Belajar & & \\
\hline & & Frequency & Percent & $\begin{array}{c}\text { Valid } \\
\text { Percent }\end{array}$ & $\begin{array}{c}\text { Cumulative } \\
\text { Percent }\end{array}$ \\
\hline Valid & 80 & 1 & 0,6 & 0,6 & 0,6 \\
\hline & 81 & 3 & 1,9 & 1,9 & 2,6 \\
\hline & 82 & 2 & 1,3 & 1,3 & 3,9 \\
\hline & 83 & 15 & 9,7 & 9,7 & 13,6 \\
\hline & 84 & 16 & 10,4 & 10,4 & 24,0 \\
\hline & 85 & 36 & 23,4 & 23,4 & 47,4 \\
\hline & 86 & 22 & 14,3 & 14,3 & 61,7 \\
\hline & 87 & 29 & 18,8 & 18,8 & 80,5 \\
\hline & 88 & 15 & 9,7 & 9,7 & 90,3 \\
\hline & 89 & 13 & 8,4 & 8,4 & 98,7 \\
\hline & 90 & 1 & 0,6 & 0,6 & 99,4 \\
\hline & 91 & 1 & 0,6 & 0,6 & 100,0 \\
\hline & Total & 154 & 100,0 & 100,0 & \\
\hline
\end{tabular}

Dari data di atas menunjukkan nilai tertinggi yang dicapai siswa adalah 91 dan nilai terendah yang dicapai siswa adalah 80. Sedangkan nilai yang paling banyak diperoleh oleh siswa adalah 85 sebanyak 36 siswa atau sebesar 23,4\%. Dan sebanyak 154 siswa termasuk kategori baik.

\section{Pengujian Hipotesis Penelitian}

\section{Reliabilitas Data}

Setelah dilakukan uji coba reliabilitas dengan menggunakan 25 responden dan diketahui hasilnya apakah item kuesioner tersebut reliabel atau tidak reliabel, maka disebarkanlah kuesioner tersebut ke 154 responden dan hasilnya dihitung dengan menggunakan bantuan program SPSS, maka didapatkan hasil sebagai berikut:

Tabel 4.11 Reliabilitas Kecerdasan Emosional

\begin{tabular}{|l|l|}
\hline Cronbach's Alpha & N of Items \\
\hline 0,691 & 15 \\
\hline
\end{tabular}

Berdasarkan tabel hasil pengolahan data melalui SPSS untuk variabel kecerdasan emosional didapatkan hasil Alpha Cronbach's sebesar 0,691 > 0,6.

Tabel 4.12 Reliabilitas Kompetensi Kepribadian

\begin{tabular}{|l|l|}
\hline Cronbach's Alpha & N of Items \\
\hline 0,820 & 20 \\
\hline
\end{tabular}


Berdasarkan tabel hasil pengolahan data melalui SPSS untuk variabel kecerdasan emosional didapatkan hasil Alpha Cronbach's sebesar 0,820 >0,6.

Dari dua tabel di atas dapat disimpulkan bahwa data yang didapat dari penyebaran kuesioner adalah reliabel.

Tabel 4.13 Reliabilitas

\begin{tabular}{|l|l|l|l|}
\hline Variabel & R hitung & R tabel & Reliabilitas \\
\hline Kecerdasan Emosional (X1) & 0,691 & 0,157 & Reliabel \\
\hline Kompetensi Kepribadian (X2) & 0,820 & 0,157 & Reliabel \\
\hline
\end{tabular}

\section{Validitas Data}

Setelah dilakukan uji coba validitas dengan menggunakan 25 responden dan diketahui hasil item kuesioner yang valid dan tidak valid, item kuesioner yang valid akan digunakan untuk penelitian selanjutnya sedangkan yang tidak valid akan diperbaiki, maka kemudian disebarkan kuesioner tersebut ke 154 responden dan hasilnya dihitung dengan menggunakan bantuan program SPSS, maka didapatkan hasil sebagai berikut:

Tabel 4.14 Validitas Kecerdasan Emosional Guru

\begin{tabular}{|l|r|r|r|r|}
\hline \multicolumn{5}{|c|}{ Item-Total Statistics } \\
\hline & $\begin{array}{c}\text { Scale } \\
\text { Itean if } \\
\text { Deleted }\end{array}$ & $\begin{array}{c}\text { Scale } \\
\text { Variance if } \\
\text { Item } \\
\text { Deleted }\end{array}$ & $\begin{array}{c}\text { Corrected } \\
\text { Item-Total } \\
\text { Correlation }\end{array}$ & $\begin{array}{c}\text { Cronbach's } \\
\text { Alpha if } \\
\text { Item } \\
\text { Deleted }\end{array}$ \\
\hline item_1 & 59,6948 & 16,357 & 0,238 & 0,683 \\
\hline item_2 & 59,1494 & 16,429 & 0,288 & 0,678 \\
\hline item_3 & 59,5779 & 16,951 & 0,084 & 0,703 \\
\hline item_4 & 59,5065 & 16,618 & 0,169 & 0,691 \\
\hline item_5 & 59,2273 & 16,111 & 0,335 & 0,672 \\
\hline item_6 & 59,4351 & 15,908 & 0,327 & 0,672 \\
\hline item_7 & 59,5584 & 16,340 & 0,260 & 0,680 \\
\hline item_8 & 59,6818 & 16,192 & 0,267 & 0,679 \\
\hline item_9 & 59,3961 & 15,483 & 0,375 & 0,666 \\
\hline item_10 & 59,4286 & 16,769 & 0,169 & 0,690 \\
\hline item_11 & 59,9156 & 14,614 & 0,433 & 0,655 \\
\hline item_12 & 59,4870 & 15,454 & 0,369 & 0,666 \\
\hline item_13 & 59,8052 & 15,073 & 0,375 & 0,665 \\
\hline item_14 & 59,4286 & 15,711 & 0,327 & 0,672 \\
\hline item_15 & 59,4351 & 14,953 & 0,417 & 0,659 \\
\hline
\end{tabular}

Berdasarkan tabel diatas setelah melalui hasil pengolahan data melalui program SPSS untuk variabel kecerdasan emosional, maka dapat diketahui dari 15 pernyataan diatas 
semuanya termasuk valid karena berada diatas nilai produk momen untuk 154 responden yaitu 0,157 , jadi $r$ hitung $>r$ tabel.

Tabel 4.15 Validitas Kompetensi Kepribadian Guru

\begin{tabular}{|c|c|c|c|c|}
\hline \multicolumn{5}{|c|}{ Item-Total Statistics } \\
\hline & Scale & Scale & & Cronbach's \\
\hline & Mean if & Variance if & Corrected & Alpha if \\
\hline & Item & Item & Item-Total & Item \\
\hline & Deleted & Deleted & Correlation & Deleted \\
\hline item_1 & 81,9740 & 34,457 & 0,407 & 0,811 \\
\hline item_2 & 81,9740 & 33,986 & 0,447 & 0,809 \\
\hline item_3 & 82,0519 & 34,769 & 0,299 & 0,817 \\
\hline item_4 & 81,7857 & 35,189 & 0,339 & 0,815 \\
\hline item_5 & 81,8571 & 35,666 & 0,223 & 0,820 \\
\hline item_6 & 82,2468 & 33,285 & 0,405 & 0,812 \\
\hline item_7 & 82,1104 & 33,942 & 0,450 & 0,809 \\
\hline item_8 & 82,3247 & 33,449 & 0,470 & 0,808 \\
\hline item_9 & 82,0584 & 33,820 & 0,479 & 0,808 \\
\hline item_10 & 82,2662 & 34,301 & 0,368 & 0,813 \\
\hline item_11 & 82,1623 & 33,287 & 0,534 & 0,805 \\
\hline item_12 & 81,8571 & 35,509 & 0,302 & 0,816 \\
\hline item_13 & 82,0909 & 34,671 & 0,392 & 0,812 \\
\hline item_14 & 82,2662 & 34,510 & 0,361 & 0,814 \\
\hline item_15 & 82,4481 & 32,576 & 0,512 & 0,805 \\
\hline item_16 & 81,9351 & 33,852 & 0,471 & 0,808 \\
\hline item_17 & 82,0909 & 34,881 & 0,361 & 0,814 \\
\hline item_18 & 81,9286 & 34,864 & 0,336 & 0,815 \\
\hline item_19 & 81,8831 & 34,771 & 0,355 & 0,814 \\
\hline item_20 & 81,7208 & 35,837 & 0,247 & 0,819 \\
\hline
\end{tabular}

Berdasarkan tabel diatas setelah melalui hasil pengolahan data melalui program SPSS untuk variabel kompetensi kepribadian, maka dapat diketahui dari 20 pernyataan diatas semuanya termasuk valid karena berada diatas nilai produk momen untuk 154 responden yaitu 0,157 , jadi $r$ hitung $>r$ tabel.

\section{Uji Regresi Linier Berganda}

Analisis regresi berganda bertujuan untuk mengetahui ada atau tidaknya pengaruh dua atau lebih variabel bebas (X) terhadap variabel terikat (Y). Uji t bertujuan untuk mengetahui ada atau tidaknya pengaruh parsial (sendiri) yang diberikan variabel bebas (X) terhadap variabel terikat (Y). Uji f bertujuan untuk mengetahui ada atau tidaknya pengaruh simultan (bersama-sama) yang diberikan variabel bebas (X) terhadap variabel terikat (Y). Koefisien diterminasi berfungsi untuk mengetahui berapa persen pengaruh yang diberikan variabel bebas $(\mathrm{X})$ terhadap variabel terikat $(\mathrm{Y})$. 
Untuk mengetahui apakah kecerdasan emosional guru berpengaruh terhadap prestasi belajar siswa dan kompetensi kepribadian guru berpengaruh terhadap prestasi belajar siswa,maka peneliti menggunakan bantuan program SPSS dengan hasil sebagai berikut:

Tabel 4.19 Coefficients

\begin{tabular}{|c|c|c|c|c|c|c|c|c|}
\hline \multicolumn{9}{|c|}{ Coefficients $^{\mathrm{a}}$} \\
\hline & & \multicolumn{2}{|c|}{$\begin{array}{c}\text { Unstandardized } \\
\text { Coefficients }\end{array}$} & \multirow{2}{*}{$\begin{array}{c}\text { Standardized } \\
\text { Coefficients } \\
\text { Beta }\end{array}$} & \multirow[b]{2}{*}{$\mathrm{t}$} & \multirow[b]{2}{*}{ Sig. } & \multicolumn{2}{|c|}{$\begin{array}{c}\text { Collinearity } \\
\text { Statistics }\end{array}$} \\
\hline \multicolumn{2}{|l|}{ Model } & B & Std. Error & & & & Tolerance & VIF \\
\hline \multirow[t]{3}{*}{1} & (Constant) & 66,621 & 2,127 & & 31,319 & 0,000 & & \\
\hline & \begin{tabular}{|l|} 
Kecerdasan \\
Emosional
\end{tabular} & 0,130 & 0,040 & 0,274 & 3,264 & 0,001 & 0,604 & 1,656 \\
\hline & \begin{tabular}{|l|} 
Kompetensi \\
Kepribadian
\end{tabular} & 0,126 & 0,027 & 0,384 & 4,568 & 0,000 & 0,604 & 1,656 \\
\hline
\end{tabular}

Dasar pengambilan keputusan uji t adalah jika nilai signifikansi $<0,05$, maka terdapat pengaruh variabel $X$ terhadap variabel $Y$. Namun jika nilai signifikansi $>0,05$, maka tidak terdapat pengaruh variabel $X$ terhadap variabel $Y$. Untuk variabel kecerdasan emosional guru $\mathrm{X} 1$ nilai signifikansi 0,001 $<0,05$, maka terdapat pengaruh variabel X1 terhadap variabel Y, Ho ditolak dan Ha diterima. Untuk variabel kompetensi kepribadian guru X2 nilai signifikansi $0,000<0,05$, maka terdapat pengaruh variabel X2 terhadap variabel Y, Ho ditolak dan Ha diterima.

Untuk mengetahui pengaruh kecerdasan emosional guru dan kompetensi kepribadian guru terhadap prestasi belajar siswa secara bersamaan, maka peneliti menggunakan bantuan program SPSS dengan hasil sebagai berikut :

Tabel 4.20 Anova

\begin{tabular}{|c|c|c|c|c|c|c|}
\hline \multicolumn{7}{|c|}{ ANOVA $^{a}$} \\
\hline \multicolumn{2}{|l|}{ Model } & $\begin{array}{l}\text { Sum of } \\
\text { Squares }\end{array}$ & df & Mean Square & $\mathrm{F}$ & Sig. \\
\hline \multirow[t]{3}{*}{1} & Regression & 219,346 & 2 & 109,673 & 41,641 & $.000^{\mathrm{b}}$ \\
\hline & Residual & 397,699 & 151 & 2,634 & & \\
\hline & Total & 617,045 & 153 & & & \\
\hline
\end{tabular}

Dasar pengambilan keputusan uji f adalah jika nilai signifikansi $<0,05$, maka terdapat pengaruh variabel X secara simultan terhadap variabel Y. Namun jika nilai signifikansi $>0,05$, maka terdapat pengaruh variabel X secara simultan terhadap variabel Y. Dari tabel di atas bahwa nilai signifikansi $0,000<0,05$, maka terdapat pengaruh secara simultan varibel $\mathrm{X}$ terhadap variabel $Y$, Ho ditolak dan Ha diterima. 
Tabel 4.21 Model Summary

\begin{tabular}{|l|r|r|r|r|r|}
\hline \multicolumn{7}{|c|}{ Model Summarv } \\
\hline Model & $\mathrm{R}$ & R Square & $\begin{array}{c}\text { Adjusted R } \\
\text { Square }\end{array}$ & $\begin{array}{r}\text { Std. Error of } \\
\text { the Estimate }\end{array}$ & $\begin{array}{r}\text { Durbin- } \\
\text { Watson }\end{array}$ \\
\hline 1 & .596 & 0,355 & 0,347 & 1,623 & 1,379 \\
\hline a. Predictors: (Constant), Kompetensi Kepribadian, Kecerdasan Emosional \\
\hline
\end{tabular}

Berdasarkan tabel di atas bahwa R Square sebesar 0,355, hal ini mengandung arti bahwa pengaruh X1 dan X2 terhadap variabel Y adalah 35,5 \%.

\section{Pembahasan Hasil Penelitian}

Berdasarkan dari semua hasil uji hipotesis yang telah dilakukan melalui bantuan program SPSS, maka peneliti akan memaparkan hasil penelitian sebagai berikut :

1. $\mathrm{H} 1=$ Terdapat pengaruh kecerdasan emosional guru (X1) terhadap prestasi belajar siswa (Y), Ho ditolak dan Ha diterima.

2. $\mathrm{H} 2$ = Terdapat pengaruh kompetensi kepribadian guru (X2) terhadap prestasi belajar siswa (Y), Ho ditolak dan Ha diterima.

3. $\mathrm{H} 3$ = Terdapat pengaruh $35,5 \%$ kecerdasan emosional guru (X1) dan kompetensi kepribadian guru (X2) secara bersama-sama terhadap prestasi belajar siswa (Y).

Dengan demikian bahwa kecerdasan emosional guru madrasah aliyah Qotrun Nada di Depok memberikan pengaruh terhadap prestasi belajar siswa madrasah aliyah Qotrun Nada di Depok. Kompetensi kepribadian guru madrasah aliyah Qotrun Nada di Depok memberikan pengaruh terhadap prestasi belajar siswa madrasah aliyah Qotrun Nada di Depok. Begitu pula kecerdasan emosional dan kompetensi kepribadian guru madrasah aliyah Qotrun Nada di Depok memberikan pengaruh 35,5\% terhadap prestasi belajar siswa madrasah aliyah Qotrun Nada di Depok.

Berdasarkan pemaparan di atas menunjukkan bahwa kecerdasan emosional dan kompetensi kepribadian guru dapat mempengaruhi prestasi belajar siswa madrasah aliyah Qotrun Nada di Depok, memungkinkan juga bahwa ada faktor lain yang dapat mempengaruhi prestasi belajar. Dalam hal ini maka siswa madrash aliyah Qotrun Nada di Depok sebaiknya belajar dan berusaha lebih maksimal untuk mengenal emosi diri, orang lain dan dapat mengelolanya dengan baik, serta harus mampu untuk memotivasi diri sendiri agar dapat membina hubungan baik dengan orang lain.

Jika dalam teori yang mengatakan bahwa kecerdasan emosional dan kompetensi kepribadian merupakan bagian yang mempengaruhi prestasi belajar, maka sama hal tersebut memberikan pengaruh di madrasah aliyah Qotrun Nada di Depok, pada saat yang bertepatan peneliti melakukan penelitian tersebut. Mungkin hal tersebut juga bisa berpengaruh pada saat dan waktu yang berbeda, atau mungkin hal tersebut dapat berpengaruh di tempat yang berbeda.

Siswa-siswa madrasah aliyah Qotrun Nada Depok terbiasa dengan aktifitas dan proses belajar mandiri, serta menjalani aktifitas keagamaan atau kebiasaan spiritual yang tidak 
pernah ditinggalkan. Hal ini memungkinkan mereka tetap bisa berprestasi dengan baik, bisa jadi hal ini juga dapat mempengaruhi prestasi belajar siswa.

\section{E. PENUTUP \\ Kesimpulan}

Berdasarkan hasil analisa dan pembahasan maka dapat disimpulkan sebagai berikut :

1. Ada hubungan korelasi yang erat antara kecerdasan emosional guru dengan prestasi belajar siswa, sehingga ada pengaruh yang positif dan signifikan kecerdasan emosional guru terhadap prestasi belajar siswa madrasah aliyah Qotrun Nada Depok. Hal ini dibuktikan dengan nilai signifikansi 0,001<0,05, maka terdapat pengaruh. Ho ditolak Ha diterima.

2. Ada hubungan korelasi yang erat antara kompetensi kepribadian guru dengan prestasi belajar siswa, sehingga ada pengaruh yang positif dan signifikan kompetensi Kepribadian guru terhadap prestasi belajar siswa madrasah aliyah Qotrun Nada Depok. Hal ini dibuktikan dengan nilai signifikansi $0,000<0,05$, maka terdapat pengaruh. Ho ditolak Ha diterima.

3. Ada pengaruh kecerdasan emosional dan kompetensi kepribadian guru secara bersamaan terhadap prestasi belajar siswa madrasah aliyah Qotrun Nada Depok. Hal ini dibuktikan dengan uji f nilai sinifikan 0,000 $<0,05$, maka terdapat pengaruh. Begitu pula dengan nilai R Square 35,5\% termasuk kategori nilai yang kuat.

Selain dari kecerdasan emosional dan kompetensi kepribadian guru yang dapat mempengaruhi prestasi belajar, ada faktor lain yang dapat mempengaruhi prestasi belajar diantaranya kecerdasan spiritual, kecerdasan intelektual, keluarga dan kebudayaan, peranan konsep diri dan peran jenis kelamin (menurut Rola 2006). Menurut Slameto (2003) faktor intern dan faktor ekstern juga dapat memberikan pengaruh terhadap prestasi belajar.

\section{Saran}

Berdasarkan hasil penelitian yang telah dilakukan, maka terdapat beberapa hal yang akan direkomendasikan oleh peniliti, dalam rangka meningkatkan prestasi belajar siswa madrasah aliyah Qotrun Nada Depok diantaranya :

1. Guru diharapkan lebih meningkatkan kecerdasan dan kompetensi keguruannya melalui pendidikan dan pelatihan. Baik dalam maupun luar lingkungan sekolah.

2. Guru hendaknya lebih meningkatkan dalam menjalankan tugas pokok dan fungsi guru, serta lebih memperkaya diri baik dalam aspek pengetahuan, keterampilan, kepribadian, dan emosinal serta spiritual. Dengan harapan melalui sikap tersebut akan dapat lebih berpengaruh terhadap prestasi belajar.

3. Guru disarankan agar lebih menumbuhkan kesadaran pada diri siswa untuk lebih semangat dalam meningkatkan prestasi belajar.

Selain memaparan di atas, peneliti berharap kepada para peneliti dibidang pendidikan dapat melakukan penelitian lanjutan dan mencari variabel-variabel lain, yang diduga 
memiliki korelasi dengan prestasi belajar sehingga menjadi rujukan untuk meningkatkan prestasi belajar.

Peniliti berharap semoga penelitian ini dapat memberikan manfaat yang positif bagi pihak lembaga yang terkait, dan lembaga yang mendukung dalam pelaksanaan penelitian ini.

\section{DAFTAR PUSTAKA}

Arikunto, S, 1995, Dasar-Dasar Evaluasi Pendidikan, Jakarta:Bumi Aksara. Arikunto,Suharsimi, 1992, Manajemen Penelitian,Jakarta:Reneka Cipta.

Al-Quran Terjemah kementrian agama

Bahraen, Raehanul, 2018, Psikologi Islam Yang Sempurna, Yogyakarta: Muslimafiyah Publishing.

Darajat, Zakiah, 2005, Kepribadian Guru, Jakarta:Bulan Bintang.

Djaali, 2019, Psikologi Pendidikan, Jakarta:PT Bumi Aksara.

Dahlan, Sitti Salmiah, 2011, Manajemen Pendidikan Islam, Jakarta:Rabbani Pres.

Fathur Rohman litholabi aayatil Quran

Ginanjar Agustian, 2010, Ary, Rahasia Sukses Membangun Kecerdasan Emosi dan Spiritual ESQ, Jakarta, Arga Publishing.

Goleman, Daniel, 2000, Emotional Intelligence,Kecerdasan Emosional, Jakarta:PT Gramedia pustaka utama.

Gozali, Imam, 2013, Aplikasi Analisis Multivarriete, Semarang: Badan Penerbit Universitas Diponegoro.

Hutagulung, Inge, 2007, Pengembangan Kepribadian, Jakarta:PT Indeks.

Hawi, Akmal, 2014, Kompetensi Guru Pendidikan Agama Islam, Jakarta: PT RajaGrafindo Persada.

Institut Agama Islam Nasional Laa Roiba, 2019, Buku Pedoman Penulisan Tesis, Bogor. Juni Priansa, Donni, 2017, Menjadi Kepala Sekolah Dan Guru Profesional, Bandung:CV Pustaka Setia.

Jurnal Formatif 6(3):233-245, 2016.

Koentjoroningrat, 1985, Metode-metode Penelitian Masyarakat, Jakarta: Gramedia, 1985.

Kamus Besar Bahasa Indonesia.

M. Gagne, Robert, 1975, Essential Learning Instruction, Hindale,Illionis: The Dryden Press.

Muslim, Abi al-Husain Muslim bin al-Hajjaj ibn Muslim al-Qusyairy al-Naishabury, Al-jami'AlShahih,juz 8,Beirut, Libanon: Dar al-Fikri,tt.

Mulyasa, E, 2018, Implementasi Kurikulum 2013 Revisi, Jakarta:PT Bumi Aksara. Mahmud, 2011, Metode Penelitian Pendidikan, Bandung:CV Pustaka Setia, 2011.

Moeong, Lexy J, 2005, Metode Penelitian Kualitatif, Bandung: Remaja Rosdakarya.

Musfah, Jejen, 2015, Peningkatan Kompetensi Guru, Jakarta:PRENADAMEDIA GROUP.

Ma"ruf Asmani, Jamal, 2009, 7 Kompetensi Guru menyenangkan dan Profesional, Power Books (ihdina), Jogjakarta.

Nata, Abuddin, 2008, Manajemen Pendidikan, Jakarta: Kencana Prenada Media Group. 
Rofarif, Juman, 2015, Al-Hikam Ali ibn Abi Thalib, Jakarta: Serambi Ilmu Semeta.

Rusdiana, A, dan Heryati, Yeti, 2015, Pendidikan Profesi Keguruan, Bandung:CV Pustaka Setia.

Ruswanto, Biormatika Jurnal Ilmiah FKIP Universitas Subang Vol. 3 No 2 September 2017 ISSN (p) 2461-3961 (e) 2580-6335.

Sutrisno, Edy, 2017, Manajemen Sumber Daya Manusia, Jakarta:Kencana.

Safaria, Triantoro \& Saputra, Nofrans Eka, 2009, Manajemen Emosi, Jakarta:PT Bumi Aksara.

Setiawan Dj, Otong, 2018, Pedoman Penulisan Skripsi Tesis Disertasi, Bandung: Penerbit Yrama Widya.

Sudjana, Nana, 2009, Penilaian Hasil Proses Belajar Mengajar, Bandung: PT Remaja Rosdakarya.

Sudijono, Anas, 2011, Pengantar Statistik Pendidikan,Jakarta: PT RajaGrafindo Persada.

Sugiono, 2017, Metode Penelitian, Bandung:Alfabeta.

Sukardi, 2019, Metode Penelitian Pendidikan, Jakarta: Bumi Aksara.

DPRRI 2015. Undang-Undang No. 14 tahun 2015, tentang guru dan dosen, Jakarta: DPRRI.

Wahab H.S, Abdul \& Umiarso, 2011, Kepemimpinan Pendidikan dan Kecerdasan Spiritual, Jogjakarta:AR-RUZZ MEDIA.

Winch, Guy, 2017, Pertolongan Pertama Pada Emosi, Tangerang Selatan: Gemilang. 